\title{
Comparison of Legal Systems: Legal Studies on Postponement of Debt Payment Obligations in Indonesia and Reorganization in the United States
}

\author{
Sumurung P. Simaremare ${ }^{1}$, Bismar Nasution $^{2}$, Sunarmi $^{3}$, Edi Yunara ${ }^{4}$ \\ \{sumurungpsimaremare@gmail.com ${ }^{1}$, bismar.nasution@gmail.com ${ }^{2}$, sunarmi@usu.ac.id ${ }^{3}$, \\ edi.yunara@gmail.com $\left.{ }^{4}\right\}$ \\ Universitas Sumatera Utara, Indonesia ${ }^{1,2,3,4}$
}

\begin{abstract}
Postponement of the debt payment obligation is an alternative provided to fulfill debtors' obligations to creditors. Each country has a different framework in arranging such postponement. Indonesia, which adheres to the civil law system, regulates the problem of postponement in Law Number 37 of 2004 with a deferment scheme that concentrates on a mutual agreement between debtors and creditors in debt settlement. Meanwhile, America, which adheres to the common law system, regulates the scheme through corporate reorganization as regulated in Chapter 11 of the US Bankruptcy Code which focuses more on providing opportunities for debtors to rehabilitate their companies. A comparative study is made to find out more about the debt payment postponement scheme to be used as a reference for legal reform efforts. At this point, the comparison was carried out using a statutory and conceptual approach. In America, Chapter 11 of the US Bankruptcy Code gives debtors flexibility (i.e., time flexibility) in carrying out debt restructuring programs, while in Indonesia, postponement of debt payment obligation applies time constraints in delays and settlement of debt cases.
\end{abstract}

Keywords: Comparison of Legal Systems, Postponement of Debt Payment Obligations, Reorganization

\section{Introduction}

The concept of Postponement of Debt Payment Obligations has been recognized in Indonesia since the enforcement of concordance principles. This concept refers to the same source of bankruptcy law in Indonesia, namely Law Number 37 of 2004. The postponement concept is presented in bankruptcy law with the mode of consolidating efforts between debtors and creditors in the context of repaying debtor's obligations to creditors at a certain time, during which the peace between the two parties can be realized without neglecting the rights and obligations of each party [1].

The option offered in the Postponement is reconciliation. However, if reconciliation cannot be made, then the debtor is declared bankrupt. The reconciliation between debtors and creditors is not always successful, confirming that the concept of Postponement of Debt Payment Obligations only provides a way of delay, while the subsequent process is fully left to the parties in disputes [2]. In such a case, the legal function as a means of social engineering has not been implemented, considering that the Indonesian Bankruptcy Law has not succeeded in directing changes in the behavior of the parties in disputes to consciously achieve peace in the 
Postponement of Debt Payment Obligations. This is ineffective because any similar case will inevitably lead to bankruptcy, and not a settlement [3].

The concept of postponement applicable in the United States as stipulated in Chapter 11 of the US Bankruptcy Code and the systems adopted by Indonesia show different applications. In Indonesia, it is based on providing leeway in settling debtor's obligations to creditors, during which reconciliation between the two parties is the main goal [3]. Meanwhile, the reorganization system adopted by the United States does not consider leeway to solve financial problems. Therefore, the best option to solve such financial problems is to re-structure the business organization because the previous management was deemed incompetent in conducting its business and fulfilling the obligations.

Chapter 11 of the US Bankruptcy Code states that a bankruptcy application can be filed without waiting for insolvent status, and the filing can be made when the creditor's bill against the debtor has exceeded the existing assets [4]. Thus, debt restructuring is one of the alternatives for the settlement. Therefore, reorganization becomes an effort to make a healthier company and improve the financial condition of a business entity or corporation [5].

The comparison of the debt restructuring process applicable in Indonesia and America provides different perspectives on the debt settlement process itself. In Indonesia, debt payment postponement is more focused on the reconciliation process, while in corporate reorganization applicable in the United States, debtors have the flexibility to rehabilitate their business without neglecting the debt. Such differences can be used as the basis for legal changes to be applied in the future.

\section{Arrangements for Postponement of Debt Payment Obligations in Indonesia and Reorganization in the United States}

The legal comparison in Indonesia and the United States is carried out through a statutory approach, a comparative approach, and a conceptual approach. A legal comparison is a process of studying, understanding, and aligning concepts using a functional and problem-solving approach as a measure of comparison [6]. The general reasons underlying a comparative process are the prospect of forming a world legal system and the diversity of laws which is highly correlated with the history of a country [7]. Also, the fact that the diversity of laws certainly requires the initiative to acknowledge and accept even though there are many debates about the diversity and uniformity of laws. Then, the development of comparative laws inspires an appreciative step in respecting legal diversity. Nevertheless, such development does not always indicate an increasing appreciation of law diversity, it just increases an understanding that global legal unification is continuously defeated by various pluralizing particularities [8]. This is in line with Glenn who believes that harmonious diversity of law at the global level is a natural phenomenon and should, therefore, be prioritized [9].

David and Brierly argue that different political views can lead to different laws and state structures, which in turn nullify the assumption that western laws are viewed as more civilized and superior than other laws [6]. On the other hand, an emphasis and imposition of the view that progressive initiatives related to social influences on law must come from Western countries put aside other legal cultures to develop their legal systems. For example, comparing the law of postponement of debt payment obligations in Indonesia and reorganization in the United States will give birth to a deeper understanding of the debt restructuring process in the two countries. 
The process of postponement of debt payment obligations and corporate reorganization are methods that can be taken by debtors who experience payment difficulties in fulfilling their obligations. Both methods can be used to protect ongoing businesses from the threat of liquidation upon filing a bankruptcy application [10]. Taking into account the interests and conditions of the debtors and creditors, the selected debt and credit settlement process should have a positive impact on both parties. Postponement through debt restructuring and corporate reorganization are important elements in the framework of restoring the national economy, through which companies experiencing financial problems can agree with creditors to settle obligations existing among them.

Postponement of Debt Payment Obligations, especially in Indonesia, is a term that is often associated with the problem of "insolvency" or "insolvent condition", namely the inability of debtors to pay their overdue and collectible debts. Their debts can be collected at any time unless they have the postponement that must be determined by the court judge on their request for their "insolvency" condition [11]. The parties who are entitled to apply are:

a. Debtors who have more than 1 creditor, or debtors who are not able or estimate that they will not be able to continue to pay their overdue and collectible debts, can apply for a postponement of debt payment obligations and reconciliation including an offer of partial or full payment to creditors (Article 222 Paragraph (2) of the Bankruptcy Law).

b. Creditors (in this case both concurrent and preferential creditors) who estimate that debtors are unable to pay their overdue and collectible debts can apply for a postponement to allow the debtors for reconciliation including an offer of partial or full payment to the creditors (Article 222 Paragraph (3) of the Bankruptcy Law).

c. Exceptions are given to Bank Debtors, Securities Companies, Stock Exchanges, Clearing Guarantee Institutions, Depository and Settlement Institutions, Insurance Companies, Reinsurance Companies, Pension Funds, and State-Owned Enterprises engaged in the public interest.

The description obviously shows that applying for a postponement of debt payment obligations is not only for the interests of the debtors but also the creditors. In this case, the integrity of the debtors becomes a test of whether they want to pay off the debt or not. Generally, the postponement is divided into two [12]:

a. Applying for postponement of pure debt payment obligations (voluntary petition)

A voluntary petition is an application submitted by the debtor as the applicant without attracting the other party (the creditor) as the respondent, and the litigation initiative rests with the debtor.

b. Request for postponement of impure debt payment obligations (involuntary petition)

An involuntary petition is an application submitted by the debtor as a deterrent or counter against the bankruptcy application submitted by the creditor against the debtor, and the litigation initiative rests with the creditor.

Meanwhile, based on the time of Court decision against the debtor, postponement is divided into two types, namely:

a. Temporary postponement of debt payment obligations

If the application has been submitted by a debtor, the court within 3 days from the date of application registration must grant a temporary postponement and must appoint a Supervisory Judge from the Court Judge and one or more administrators who, together with the debtor, take care of the debtor's assets. If the application is submitted by the creditor, the court within 20 days from the date of application registration must grant a temporary postponement and must appoint a Supervisory Judge from the Court Judge and 1 or more administrators who, together with the debtor, take care of the debtor's assets [13]. 
b. Permanent postponement of debt payment obligations

During the court session, the Judge must listen to the Debtor, the Supervisory Judge, the Administrators, and the Creditor who attend the trial, or to their representatives or the attorney appointed based on a power of attorney. At the hearing, the creditor must determine whether to grant or refuse the permanent postponement. If granted, the permanent postponement along with its extension must not exceed 270 days after the temporary postponement is disclosed.

The postponement of debt payment obligations determined by the Court results in the "temporary postponement" of overdue debt until a new agreement is reached between the creditor and the debtor regarding the terms and new payment procedures [1]. The postponement does not eliminate the obligations to pay the debt, nor does it reduce the amount of debt; but it only has the character of a "temporary postponement" to achieve a "new scheduling" for the overdue debt. The period of postponement, either temporary or permanent, along with its extension shall not exceed 270 days from the date since the stipulation of the decision for temporary postponement is disclosed [14].

\section{Submission Requirements and Legal Effects on the Legal Status of Debtors in Indonesia and the United States}

\subsection{Submission requirements in Indonesia and the United States}

The most important requirement in applying for postponement of debt payment obligations as stated in Article 222 Paragraph (1) of Law Number 37 of 2004 is that the debtor has more than one creditor. The submission of the application can be made by both the debtor and the creditor. This is an amendment to the new bankruptcy law. In the previous law, Law Number 4 of 1998, Article 213 states that the party that can apply for postponement is the debtors. This is amended in Law Number 37 of 2004 by including creditors who can also apply. Article 222 Paragraph (3) of Law Number 37 of 2004 states that the creditors can apply for a postponement if they can determine that the debtors cannot pay their overdue and collectible debts. Meanwhile, the debtors can apply not only after they cannot pay their debts, but also when they estimate that they cannot pay their overdue and collectible debts (Article 222 Paragraph (2) of Law Number 37 of 2004). Thus, when the contents of Article 222 Paragraph (2) and Paragraph (3) are carefully examined, the differences regarding the conditions for postponement by debtors and creditors are visible [15].

Bankruptcy Law in the United States can provide a second chance for debtors to get rid of old debts that are emphasized on a fresh start concept. The evidence can be seen in the US Bankruptcy Code which gives opportunities to debtors to reorganize including corporate restructuring, debt restructuring, and so forth that are compiled in a Reorganization Plan. This regulation tends to prevent the liquidation of the debtor's company. The expected goal of Chapter 11 of the US Bankruptcy Code is to serve as a means of rehabilitation for debtors [16]. Chapter 11 prevents creditors from collecting payments for a certain time when the debtors are developing a payment plan. In exchange for retaining the debtors' assets during the Reorganization process, the debtors promise a payment derived from their future income using the retained assets. The promised payment is adjusted to the proportion of their claims to the creditors [17]. 
A bankruptcy case begins with the submission of an application to the Court that has the authority to examine a bankruptcy case (Section 301 of US Bankruptcy Code). In general, the debtors act as the applicant in the application for examination of a bankruptcy case. An application for examination of bankruptcy cases initiated by debtors is usually referred to as a voluntary petition. Creditors also have the right to apply, which is known as an involuntary petition. However, creditors have limited rights in applying for bankruptcy examinations against debtors under Chapter 7 and Chapter 11. Chapters 7, 11, 12, and 13 of Section 301 of the US Bankruptcy Code regulate the initiation of a voluntary bankruptcy case examination [18].

An application can be submitted by any party that can indeed be qualified as a debtor in the respective Chapters. This becomes the basis for the examination of the application. Therefore, under Chapter 11 of the US Bankruptcy Code, the party that can apply for voluntary bankruptcy is anyone who meets the requirements to be classified as a debtor based on the contents of Chapter 11. Section 109 (a) of the US Bankruptcy Code provides provisions regarding the restrictions on who can be a debtor in the realm of bankruptcy law:

"Notwithstanding any other provision of this section, only a person that resides or has a domicile, a place of business, or property in the United States, or a municipality, may be a debtor under this title" [12].

In the case of an application for bankruptcy submitted by a creditor, there are compulsory conditions that must be fulfilled in advance as set out in Section 303 (a) of the US Bankruptcy Code. In this regulation, an application submitted by a creditor can only be made in the case of examination of bankruptcy as listed in Chapter 7 and Chapter 11 of the US Bankruptcy Code [12]. This provision also regulates that the application must be submitted against a debtor who is classified as a debtor according to the chapter that becomes the basis for examining the submitted bankruptcy case. The application shall be submitted to the Bankruptcy Court.

\subsection{Legal Effects on the Legal Status of Debtors in Indonesia and the United States}

The postponement of debt payment obligations affects the legal status of debtors, in particular concerning the actions they can take. It affects the legal status of debtors regarding their actions against their wealth. Article 240 Paragraph (1) of Law Number 37 of 2004 stipulates that there is a limit for a debtor to postpone debt payment to enable him/her to take any action on his/her assets. Based on the provisions of this article, a debtor requires approval from the Administrator to take care of all or part of his/her assets. If the postponement comes into effect, the debtor's power is reduced by the provisions contained in the Bankruptcy Law and the law of postponement of debt payment obligations [19].

The postponement of debt payment obligations also has legal consequences for the status of confiscation and execution of the guarantees. It results in the postponement of all execution actions that have been initiated to obtain debt repayment (Article 242 Paragraph (1) of Law Number 37 of 2004). Thus, debtors during the period of postponement cannot be forced to pay their debts because, during this period, the Commercial Court provides an opportunity for debtors to submit a reconciliation plan. This situation lasts during the temporary and permanent postponement. Furthermore, Article 242 of Law Number 37 of 2004 also stipulates that all confiscations that have been imposed are invalidated after the decision of permanent postponement is announced or after the decision on ratification of the reconciliation is legally binding. Then, at the request of the Administrator or the Supervisory Judge, if still needed, the 
Court is obliged to remove the confiscation that has been imposed on the object that belongs to the debtor's assets. This provision is waived if the Court, based on the request of the Administrator, has set a confiscation date earlier [19].

During the period of postponement, debtors cannot be forced to pay their debts as referred to in Article 242 jo. 245 Law Number 37 of 2004 . Article 245 states that:

"Payment of all debts, other than those referred to in Article 244, which have already existed before the issuance of the postponement of debt payment obligations shall not be made during the postponement, unless the payment of the debt is applied to all Creditors, according to the balance of their respective receivables, without prejudice to the validity of the provisions as referred to in Article 185 Paragraph (3)".

In its implementation, corporate reorganization as a form of legal protection for bankrupt debtors will result in juridical or legal consequences. Even since the application for bankruptcy examination under Chapter 11 of the US Bankruptcy Code was submitted, there have been consequences both for the related parties and for the implementation of the subsequent Company Reorganization process [16]. In this regard, submitting a bankruptcy application will initiate a bankruptcy case. Based on the provisions contained in the US Bankruptcy Code, the initiation of a bankruptcy case will result in two legal consequences. The first is the enactment of an automatic stay or a state of silence, and the second is the formation of an estate [20].

Automatic stay or a state of silence is a safe burrow for the bankrupt which goes into effect as soon as the petition is filed. It is a condition or period that immediately takes effect when the bankruptcy case has started which is indicated by the submission of an application for examination. This automatic stay prevents creditors from collecting debts incurred before applying [20]. Besides, creditors cannot sue debtors in court for payment. Even outside the court, creditors cannot force debtors to make payments immediately after the automatic stay has taken place.

Meanwhile, the estate in the United States Bankruptcy Act can be interpreted as:

"The accumulated non-exempt assets in a bankruptcy case, which are distributed for payment of administrative expenses and creditor's claims. Exempt laws normally apply only in favor of debtors who are natural persons, and typically protect only property used for personal rather than business purposes. They were originally intended to protect the tax base: debtors could not produce taxable wealth if they were left destitute".

After the initiation of a bankruptcy case, what is called an estate, or what is known in the Indonesian Bankruptcy Law as a bankruptcy asset, is automatically formed. Estate is an accumulation or a total of non-exempt assets in a bankruptcy case, which will later be used to pay the creditors' claims and the administrative costs incurred during the case. As an estate is a total of non-exempt assets, not all debtor's assets will automatically become bankruptcy assets or estate. This is because some parts of the debtor's assets are excluded, or are called exempt property based on the Bankruptcy Act of the United States.

There are different regulations in the Bankruptcy Law applicable in Indonesia and the United States because of two different legal systems. The difference between the two countries is focused on the problem of implementing postponement of debt payment obligations: the postponement in the concept of Bankruptcy Law in Indonesia and postponement as a result of corporate reorganization in the concept of Bankruptcy Law in the United States. The difference 
lies in the position of the postponement period. In Indonesia, postponement is the main point, while in the United States where corporate reorganization applies, it is a consequence of the submission of reorganization application. Also, the period of postponement applicable in the two countries is different. The Indonesian Bankruptcy Law regulates the limit or period for the postponement, while the US Bankruptcy Code does not provide a clear limitation on the period of postponement during the corporate reorganization. In general, the comparison of the postponement of debt payment systems between Indonesia and the United States is summarized in Table 1.

Table 1. Comparison of the postponement of debt payment obligations in Indonesia and the United States

\begin{tabular}{|c|c|c|}
\hline $\begin{array}{c}\text { Comparative } \\
\text { Aspects }\end{array}$ & Indonesia & United States \\
\hline $\begin{array}{l}\text { Postponement of } \\
\text { Debt Payment } \\
\text { Obligations }\end{array}$ & $\begin{array}{l}\text { The main point in the process of } \\
\text { postponement }\end{array}$ & $\begin{array}{l}\text { A further process for } \\
\text { reorganization application and } \\
\text { form of protection for debtors } \\
\text { against creditors as long as the } \\
\text { debtors are trying to rehabilitate } \\
\text { their business }\end{array}$ \\
\hline Postponement Term & $\begin{array}{l}\text { Determined limitation by the } \\
\text { Bankruptcy Law and } \\
\text { postponement guarantee legal } \\
\text { certainty for payments to be } \\
\text { received by creditors }\end{array}$ & $\begin{array}{l}\text { Relatively flexible because } \\
\text { debtors have discretion in } \\
\text { business rehabilitation as a result } \\
\text { of debt restructuring during the } \\
\text { corporate reorganization }\end{array}$ \\
\hline $\begin{array}{l}\text { Position of Debt } \\
\text { Restructuring }\end{array}$ & $\begin{array}{l}\text { Judged from the implementation } \\
\text { process of postponement }\end{array}$ & $\begin{array}{l}\text { Part of the reorganization process } \\
\text { includes restructuring of assets } \\
\text { and portfolios }\end{array}$ \\
\hline $\begin{array}{l}\text { The binding force of } \\
\text { a reconciliation plan } \\
\text { or reorganization } \\
\text { plan }\end{array}$ & $\begin{array}{l}\text { Applies to debtors, } \\
\text { Administrators, and all creditors, } \\
\text { except for separatist creditors } \\
\text { who do not approve the } \\
\text { Reconciliation Plan. (Article } 281 \\
\text { Paragraph (2) of the Bankruptcy } \\
\text { Law and law on the } \\
\text { postponement of debt payment } \\
\text { obligations). }\end{array}$ & $\begin{array}{l}\text { Applies to debtors, creditors, and } \\
\text { parties who take legal actions } \\
\text { based on the provisions contained } \\
\text { in the Reorganization Plan, } \\
\text { (Section } 1141 \text { (a) of the US } \\
\text { Bankruptcy Code) }\end{array}$ \\
\hline
\end{tabular}

Based on the description in Table 1, there are different processes in the debt payment postponement system applicable in Indonesia and the United States. The differences are mainly based on the different legal systems adopted by the two countries: Indonesia adopts a civil law system, while the United States adopts a common law system. This leads to a different spirit in implementing the process of debt payment postponement. As displayed in Table 1, the postponement in Indonesia is the core of the postponement of debt payment, while such postponement in America is more focused on debt reconstruction as the manifestation of a corporate reorganization. Thus, at this point, the debtors in the United States have the opportunity to improve their financial profiles without getting excessive burdens from creditors but still not leaving their obligations on the debt. Furthermore, Table 1 also displays that the process of corporate reorganization in the United States provides full discretion for debtors in 
rehabilitating their business. This is shown through the flexibility to carry out their debt restructuring which includes asset and portfolio restructuring. In Indonesia, on the other hand, debt restructuring through postponing debt payment obligations depends on the reconciliation process between debtors and creditors. This means that debtors have a smaller chance of rehabilitating their businesses when compared to the pattern shown in the corporate reorganization process in the United States.

\section{Conclusion}

Simply, it can be concluded that there are fundamental differences in the mechanism for postponing debt payment in Indonesia and the United States. In Indonesia, postponement of debt payment obligations applies, while the United States applies corporate reorganization. This is understandable due to the different legal systems adopted by the two countries. The difference lies in the position of the postponement, it is the essence or main point in the implementation of postponement of debt payment in Indonesia, while the postponement in company reorganization that applies in the United States is the impact of the reorganization process. In other words, the corporate reorganization process provides flexibility to debtors in completing their obligations and conducting rehabilitation of their businesses.

\section{Acknowledgments}

My gratitude is addressed to the promoters and co-promoters of my dissertation for their guidance in completing writing this paper.

\section{References}

[1] T. E. Ratnawati, "Kajian Terhadap Proses Penyelesaian Perkara Kepailitan dan Penundaan Kewajiban Pembayaran Utang di Pengadilan Niaga Jakarta Pusat Kajian Terhadap Proses Penyelesaian Perkara Kepailitan dan Penundaan Kewajiban Pembayaran Utang Di Pengadilan Niaga Jakarta P," Jurnal Dinamika Hukum. Vol. 9, No. 2, pp. 144-152. 2009. doi: 10.20884/1.jdh.2009.9.2.226.

[2] H. Kurniawan, "Penundaan Pembayaran Utang pada Kepailitan Melalui Perdamaian," Focus Mahasiswa UPMI, pp. 53-65. 2019.

[3] I. F. M. Zikri, “Aspek Masalah Kepailitan dalam Tataran Teori dan Problematikanya Yang Berlaku di Indonesia," Iqtishaduna: Jurnal Ilmiah Ekonomi Kita. Vol. 4, No. 1, p. 26.2015.

[4] K. H. Kim, "A Constitutional Tango of Judicial Interpretation: the Instability of Bankruptcy Court Authority Under Article III.," Emory Bankruptcy Developments Journal. Vol. 34, No. 2. pp. 561-602. 2018.

[5] M. Fuady, Hukum Pailit. Bandung: Citra Aditya Bakti. 2002.

[6] R. David and J. E. C. Brierley, Major Legal Systems in the World Today: An Introduction to the Comparative Study of Law. Free Press. 1978.

[7] W. Menski, Perbandingan Hukum Dalam Konteks Global: Sistem Eropa, Asia, dan Afrika, 1st Ed. Vol. XVI. Bandung: Nusa Media. 2012.

[8] P. de Cruz, Perbandingan Sistem Hukum: Common Law, Civil Law dan Socialist Law, 4th ed. Bandung: Nusa Media. 2010. 
[9] M. Reimann and R. Zimmermann, The Oxford Handbook of Comparative Law. Oxford University Press. 2006.

[10] N. Nonvia, "Perubahan Pokok Dalam Peraturan Kepailitan Menurut Undang-Undang Nomor 37 Tahun 2004 Tentang Kepailitan dan Penundaan Kewajiban Pembayaran Utang," Jurnal Hukum dan Pembangunan. Vol. 36, No. 2. p. 130. 2006.

[11] D. Surjanto, "Urgensi Pengaturan Syarat Insolvensi Dalam Undang-Undang Kepailitan dan Penundaan Kewajiban Pembayaran Utang," Jurnal Hukum Kenotariatan. Vol. 3, No. 2, pp. 258-268. 2018.

[12] H. Shubhan, Hukum Kepailitan, 1st ed. Jakarta: Prenada Media. 2015.

[13] I. W. Wesna Astara, "Penundaan Kewajiban Pembayaran Utang Dalam Kepailitan (Analisis Terhadap Putusan Pengadilan Niaga Nomor: 20/Pailit/2011/Pn.Niaga.Sby)," Jurnal Magister Hukum Udayana (Udayana Master Law Journal). Vol. 4, No. 2. pp. 407-420. 2015, doi: 10.24843/jmhu.2015.v04.i02.p20.

[14] D. Budiono, "Analisis Pengaturan Hukum Acara Kepailitan dan Penundaan Kewaijjban Pembayaran Utang," Jurnal hukum Acara Perdata ADHAPER. Vol. 4, No. 2. 2018.

[15] N. Pramono and Sularto, Hukum Kepailitan dan Keadilan Pancasila - Kajian Filsafat Hukum Atas Kepailitan Badan Hukum Perseroan Terbatas di Indonesia, 2nd ed. Jakarta: Andi. 2017.

[16] C. Irianto, "The Application of the Principle of Business Continuity in Bankruptcy Settlement and Debt Payment Suspension," Jurnal Hukum dan Peradilan. Vol. 4, No. 3, pp. 399-418. 2015.

[17] S. A. Nugroho, Hukum Kepailitan di Indonesia: Dalam Teori dan Praktik Serta Penerapan Hukumnya. Jakarta: Prenadamedia. 2018.

[18] N. A. Sinaga and N. Sulisrudatin, "Hukum Kepailitan dan Permasalahannya di Indonesia," Jurnal Ilmiah Hukum Dirgantara. Vol. 7, No. 1, pp. 158-173. 2014.

[19] M. A. H. SP, Kajian Hukum Perbandingan Penundaan Kewajiban Pembayaran Utang di Indonesia Dengan Restrukturisasi Utang di Amerika Serikat. Medan: Universitas Sumatera Utara. 2003.

[20] L. Ponoroff, “Constitutional Limitations on State-Enacted Bankruptcy Exemption Legislation and the Long Overdue Case for Uniformity," SSRN Electronic Journal. Vol. 56, No. 1990. pp. 353-410. 2014, doi: 10.2139/ssrn.2421632. 